\title{
Peculiarities of morphogenesis of the endangered species of willow (Salix spp.) in vitro
}

\section{Oksana Chornobrov ${ }^{1}$,}

Svitlana Bilous $\mathbf{2}^{*}$,

Oleksandr Chornobrov ${ }^{3}$,

\author{
Maria Manko ${ }^{1}$ \\ ${ }^{1}$ Plant Biotechnology \\ Research Laboratory, \\ Boyarka Forestry Research Station, \\ National University \\ of Life and Environmental \\ Sciences of Ukraine, \\ 12 Lisodoslidna St., \\ Boyarka 08150, \\ Kyiv-Svyatoshyn distrist, Ukraine \\ ${ }^{2}$ Botany, Dendrology, and Forest Tree \\ Breeding Departament, \\ National University \\ of Life and Environmental \\ Science of Ukraine, \\ 19 General Rodimtsev St., \\ Kyiv 03041, Ukraine \\ ${ }^{3}$ Holosiivskyi National \\ Nature Park, \\ 35 Vasylia Lypkivskoho St., \\ Kyiv 03035, Ukraine
}

Conservation and reproduction of rare genotypes of Salix L. species, in particular the blunt-leaved willow (Salix retusa L.) and Jacquin's Willow (Salix alpina Scop.) that are listed in the Red Data Book of Ukraine in the status of rare and endangered species, is one of the urgent tasks of the present. The aim of research was to develop methods of introduction of $S$. retusa and $S$. alpina into in vitro culture for their mass reproduction and conservation. The plant material was cultivated on a culture medium prescribed by MS, WPM, and DKW with the addition of growth regulators according to the conventional method. Effective sterilization (over $80 \%$ ) of explants of S. retusa and S. alpina was achieved by applying a stepwise method, which consisted of consistently maintaining them in solutions $0.1 \% \mathrm{HgCl}_{2}$ and $1.0 \%$ $\mathrm{AgNO}_{3}$ for 5-6 min. Significant results in the regeneration of explants by activating the growth of available meristems in vitro were observed on MS with the addition of $0.25-0.5 \mathrm{mg} / \mathrm{l} 6$-(Furfurylaminopurine, kinetin) and $2 \mathrm{~g} / \mathrm{l}$ activated carbon. Our further research will serve as a base for developing microclonal propagation of S. retusa and S. alpina for their conservation and reproduction in vitro.

Keywords: conservation, Salix L., explants, microclonal propagation

\section{INTRODUCTION}

Conservation and reproduction of rare genotypes of Salix L. species, its natural richness, and the sources of a unique gene pool, is currently one of the urgent tasks. Such plants include

\footnotetext{
“Corresponding author. Email: forest_biotech@nubip.edu.ua
}

the blunt-leaved willow (Salix retusa L.) and Jacquin's willow (Salix alpina Scop.), the alpine species that are listed as rare and endangered species in the Red Book of Ukraine (Red Book of Ukraine, 2010-2018; Identifier of plants, 1977; Malinovsky et al., 2002).

S. alpina Scop. (syn. S. jacquiniana Willd., S. jacquinii Host.) is a relict species with a disjunctive 
habitat in Central Europe. In Ukraine, the species is spread in the Carpathian alpine zone of the area of the Svydovets Mountain at the height of $1880 \mathrm{~m}$ above sea level. Alpine willow is a dioecious gametophyte, mezohygrophyte, and microtermal species that grows in damp limestone rocks in the structure of Salicion retuse and Androsation alpine union groups.

S. alpina is a low-growing shale bush, $2-15 \mathrm{~cm}$ tall. Young leaves are pubescent, adults are bare, only with cilia along the edge, reversed, whole, brilliant, dark green from above, up to $2 \mathrm{~cm}$ in length.

Bract-shaped parts are 1-3 mm long, reddish, dark on the top, hairy. The seed-bud is reddish, on a very short leg, pubescent in a young condition. The column is short; the pistil is bifurcate and reddish. Fruit box is grayish pubescent (Malynovskyi et al., 2002).

In Ukraine, specimens of S. alpina have a status of the disappearing species and are represented by a single isolated population occupying a small area and with a small number of individuals. The reasons for the change in the size of the species are associated with narrow ecological-coenotic amplitude, which is limited by specific environmental conditions and the influence of recreation. Plants are protected in the Carpathian Biosphere Reserve. They grow on crude limestone rocks in the alpine belt (Red Book of Ukraine, 2010-2018; Identifier of Plants, 1977; Ishchuk, 2017).

S. retusa is a Central European species with a disjunctive habitat on the eastern limits of distribution in the array of Montenegro. It grows in alpine and subalpine zones, mountain rocky slopes and rocky tops, at an altitude of $1750-2000 \mathrm{~m}$ above sea level. S. retusa is protected in the Carpathian Biosphere Reserve and Carpathian National Park (Ishchuk, 2017).

S. retusa is a creeping bush, $10-30 \mathrm{~cm}$ tall, with branched shoots of brown colour. The leaves are green, shiny, and reversible, with weak or strongly pronounced leaf venation, $0.8-3.5 \mathrm{~cm}$ long and $0.5-1.1 \mathrm{~cm}$ widthways (Red Book of Ukraine, 2010-2018; Identifier of Plants, 1977; Ishchuk, 2017).
Both species belong to the Salicaceae family. The areas of their distribution in Ukraine are the alpine belt of the Carpathians. Plants reproduce primarily from seeds and by vegetative processes (Red Book of Ukraine, 2010-2018; Malynovskyi et al., 2002).

Current situation with preservation of endangered biological diversity and their scientific reproduction role are regulated by a number of international and national regulations and standards, in particular the Convention on the Protection of Biological Diversity (Rio de Janeiro, 1992), "All-European Strategy for the Conservation of Biological and Landscape Diversity” (Pan-European Strategy, 1995), “The Concept for the Conservation of Biological and Landscape Diversity of Ukraine" (Resolution of the Cabinet of Ministers of Ukraine, 1997), as well as the laws of Ukraine "On Environmental Protection", "On the Nature Reserve Fund of Ukraine", and "On Plant World" (Laws of Ukraine, 1991; 1992; 1999).

One of the approaches to solving the problem is preservation of plant tissue culture in vitro. The method of culture of isolated tissues and organs in vitro allows obtaining healthy, genetically homogeneous plants throughout a year from a minimum amount of donor material (Butenko, 1964; Kalinin et al., 1980; Cell and Tissue Culture in Forestry, 1987).

For some genotypes of Salicaceae family Mirb., microclonal propagation technologies, such as the microclonal reproduction technology for individual genotypes of the family Salicaceae Mirb., have been tested and developed by a number of authors (Mohan, Ishii, 2003; Read, Bavougian, 2013; Bilous et al., 2017) for some genotypes of Salix L. (Park et al., 2008; Shi, 2014; Kandel, 2017).

However, in current scientific literature there are no studies on micropropagation of S. alpina and S. retusa.

\section{METHODS}

Objects selected in September 2017 from plant materials of $S$. alpina and $S$. retusa were 3-4-year-old donor plants. Ten to twenty pieces 
of samples of live plant material were used in $4-5$ repetitions. For obtaining aseptic tissue culture in vitro, 5-10 cm long shoots were used. Aseptic conditions were based on commonly accepted methods in biotechnology that were modified by the authors in the process of work (Butenko, 1964; Murashige, 1974; Kalinin et al., 1980; Smith, 2012). Shoot fragments $10-15 \mathrm{~mm}$ in length and with one lateral bud were used as explants. Sterilization of plant material consisted of soaking it in a soapy liquid and then under running tap water (15-20 min in each), rinsing with distilled water (for 1-2 min), treating with $70 \%$ alcohol (for 30-60 sec), and using a number of sterilizing substances: $0.1 \% \mathrm{HgCl}_{2}$ (for 5-20 min), 1.0\% $\mathrm{AgNO}_{3}$ (for 5-20 min), 2.5\% $\mathrm{NaClO}$ (for 5-20 min), and 4-fold washing in sterile distilled water (for 4-5 min). The explants were introduced into the culture in vitro on the hormone-less culture medium prescribed by MS (Murashige, Skoog, 1962), WPM (McCown, Lloyd, 1981), DKW (Driver, Kuniyuki, 1984) and supplemented with $100 \mathrm{mg} / \mathrm{l}$ myo-Inositol, $30 \mathrm{~g} /$ lsucrose, and 7.0-7.3 g/l microbiological agar; the cycle of cultivation was 25-30 days.

The regenerative ability of the plant material in vitro was studied on a nutrient medium MS with the addition of cytokinin: 2-iP $(6-\gamma, \gamma-$ Dimethylallylaminopurine), BA (6-Benzyladenine), kinetin (6-Furfurylaminopurine). In some variants of the nutrient medium, MS was supplemented with $2 \mathrm{~g} / \mathrm{l}$ activated carbon. The acidity index $(\mathrm{pH})$ was adjusted to the level of 5.7-5.9. MS-based media were used as control. The regenerative ability of explants in vitro was studied on cultivation days 35-40.

The plant material was cultivated in a light room at a temperature of $24 \pm 1^{\circ} \mathrm{C}$ with lighting of 2000-3000 Lux with a 16-hour photoperiod and a relative humidity of $70-75 \%$. The following study methods were applied: biotechnological (plant tissue culture in vitro, microclonal propagation), statistical (average, standard error, single-factor dispersion analysis). Experimental data were calculated using statistical program MS Excel.

\section{RESULTS AND DISCUSSION}

Analysis of variance revealed that concentration of different sterilization solutions and its interaction with S. retusa and S. alpina had significant difference in overcoming contamination and improving survival of shoot tip explants (Table 1).

It was established that the following solutions were inappropriate for sterilization of explants of S. retusa and S. alpina plants: $1.0 \%$ $\mathrm{AgNO}_{3}$ for 5-20 min (variants 4, 5, 6), 2.5\% NaClO for 5-20 min (variants $7,8,9$ ), and $0.1 \%$

Table 1. Efficiency of sterilization of explants of S. retusa and S. alpina plants in vitro

\begin{tabular}{|c|c|c|}
\hline Variant of experiment & Sterilization requirements & $\begin{array}{c}\text { Efficiency of sterilization of } \\
\text { explants, } \%\end{array}$ \\
\hline 1 & $0.1 \% \mathrm{HgCl}_{2}$ duration $5-6 \mathrm{~min}$ & $38.8 \pm 4.3$ \\
\hline 2 & $0.1 \% \mathrm{HgCl}_{2}$ duration $15-16 \mathrm{~min}$ & $72.5 \pm 4.8$ \\
\hline 3 & $0.1 \% \mathrm{HgCl}_{2}$ duration $19-20 \mathrm{~min}$ & $65.0 \pm 6.5$ \\
\hline 4 & $1.0 \% \mathrm{AgNO}_{3}$ duration $5-6 \mathrm{~min}$ & $20.0 \pm 4.6$ \\
\hline 5 & $1.0 \% \mathrm{AgNO}_{3}$ duration $15-16 \mathrm{~min}$ & $31.2 \pm 5.5$ \\
\hline 6 & $1.0 \% \mathrm{AgNO}_{3}$ duration $19-20 \mathrm{~min}$ & $32.5 \pm 5.2$ \\
\hline 7 & $2.5 \% \mathrm{NaClO}$ duration $5-6 \mathrm{~min}$ & $33.8 \pm 4.3$ \\
\hline 8 & $2.5 \% \mathrm{NaClO}$ duration $15-16 \mathrm{~min}$ & $50.0 \pm 5.8$ \\
\hline 9 & $2.5 \% \mathrm{NaClO}$ duration $19-20 \mathrm{~min}$ & $40.0 \pm 4.1$ \\
\hline 10 & $\begin{array}{l}\text { consequential staying in solutions for } \\
5-6 \text { min in each liquid: } 0.1 \% \mathrm{HgCl}_{2} \\
1.0 \% \mathrm{AgNO}_{3} 2.5 \% \mathrm{NaClO}\end{array}$ & $85.0 \pm 6.5$ \\
\hline
\end{tabular}


$\mathrm{HgCl}_{2}$ for 5-6 minutes (variant 1), since these procedures recorded a rather small efficiency.

According to our observations, the majority $(60 \%)$ of all infections of explants were fungi (they appeared on days 3-6 of cultivation, (Fig. 1(a)), followed by bacterial inoculation $-30 \%$ (showed somewhat later, days 5-15), while the mixed type of infection reached no more than 10\% (appeared on days 3-15).

Effective sterilization (over $80 \%$ ) of S. retusa and $S$. alpina explants was achieved by applying a stepwise method, which consisted of consistently maintaining them in a number of solutions, for 5-6 min in each: $0.1 \% \mathrm{HgCl}_{2}, 1.0 \%$ $\mathrm{AgNO}_{3}$, and 2.5\% $\mathrm{NaClO}$ (Fig. 1(b, c). A significant percentage of aseptic microshoot fragments (over $70 \%$ ) were obtained by using $0.1 \%$ $\mathrm{HgCl}_{2}$ for $15-16$ min.

In order to grow an isolated culture of in vitro plants of the Salicaceae family, the main nutrient media of the MS, WPM and DKW have been known to be used. In our research, they were modified and tested for the suitability of obtaining regenerative explants (Fig. 2).
Experimental results of study of the regenerative capacity of plant explants showed the expediency of using the MS nutrient medium as a base at the initial stages (regeneration frequency was $93.3 \pm 3.3 \%$ for $S$. retusa, and $83.3 \pm 8.8-$ S. alpina).

The influence of nutrient components on the regenerative capacity of explants was statistically significant at $\alpha=0.05\left(\mathrm{~F}_{\text {cal. }}>\mathrm{F}_{\text {cr }}\right.$; for $S$. retusa: $\mathrm{F}_{\text {cal. }}=19.91, \mathrm{~F}_{\text {cr }}=5.14 ;$ S. alpina: $\mathrm{F}_{\text {cal. }}=14.36$, $\left.\mathrm{F}_{\mathrm{cr}}=5.14\right)$.

After obtaining aseptic viable plant material on basal MS medium (by using a range of antioxidants) (Fig. 1(d)), they were cut into 1.0$1.2 \mathrm{~cm}$ fragments and transferred to the MS nutrient medium modified (Table 2 ) by growth regulators: $0.25-0.5 \mathrm{mg} / \mathrm{l}$ kinetin, $0.5-1.0 \mathrm{mg} / \mathrm{l}$ BA, and 2-iP.

Significant results on the regeneration of explants by activating the growth of available meristems in vitro were recorded on MS with the addition of $0.25-0.5 \mathrm{mg} / \mathrm{l}$ kinetin and $2 \mathrm{~g} / \mathrm{l}$ activated carbon. Activation of plant microshoots $2.5-4.0 \mathrm{~cm}$ in length with characteristic

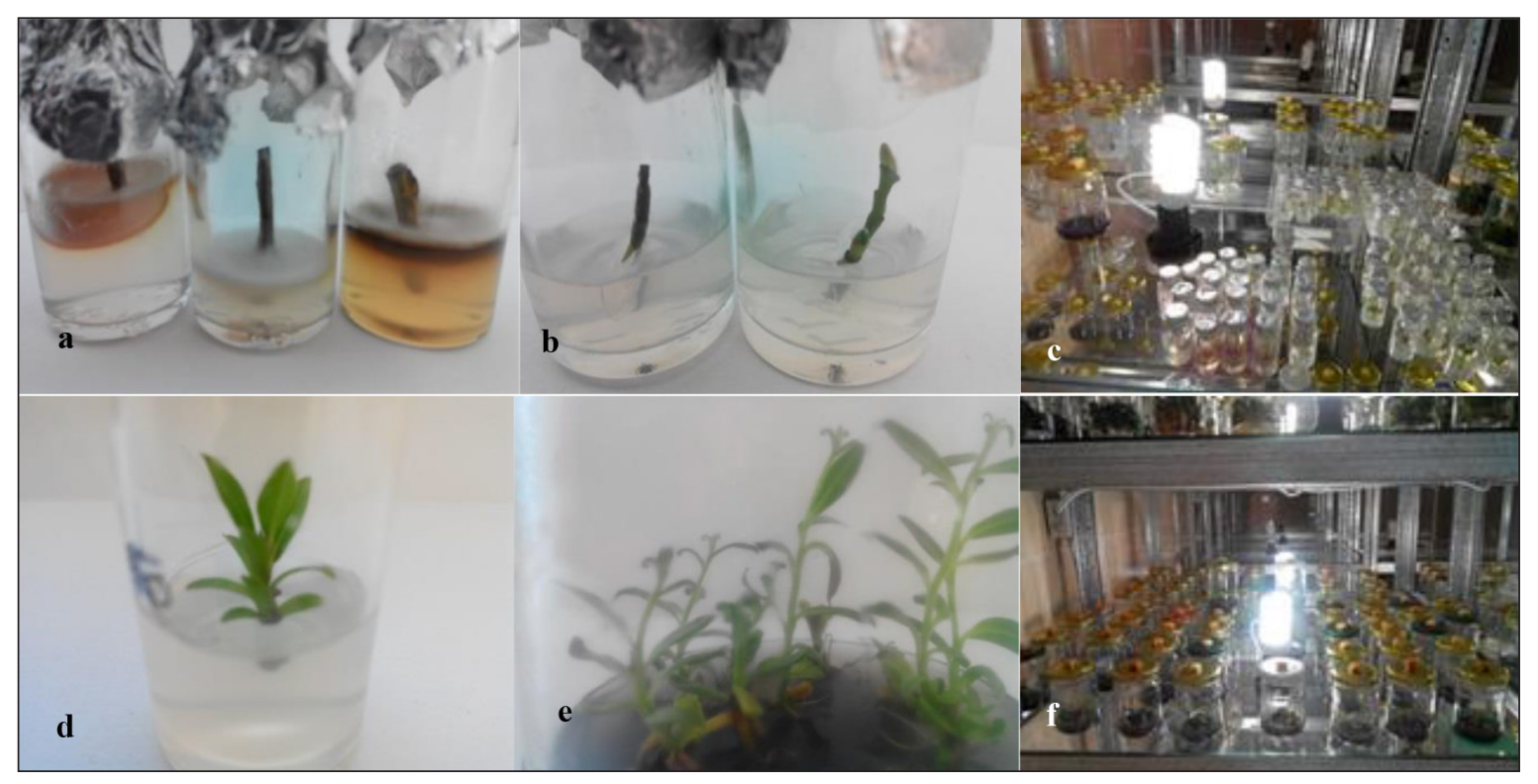

Fig. 1. Order of priorities in stages of reproduction of $S$. retusa and S. alpina by tissue culture method in vitro: a - infected plant material, on day 5 of cultivation; $\mathbf{b}$ - aseptic S. alpina explants, day 15 of cultivation; c - aseptic viable $S$. retusa explants in a cultural room under controlled conditions; $\mathbf{d}$ - proliferation of S. retusa micro segments (basal MS media) at the stage of introduction into in vitro culture; e - S. alpina microshoots (MS medium with $0.25 \mathrm{mg} / \mathrm{l}$ kinetine and $2.0 \mathrm{~g} / \mathrm{l}$ activated charcoal); $\mathbf{f}-\mathrm{S}$. retusa plants (MS medium with $0.5 \mathrm{mg} / \mathrm{l}$ kinetine and $2.0 \mathrm{~g} / \mathrm{l}$ activated charcoal) in a culture room 


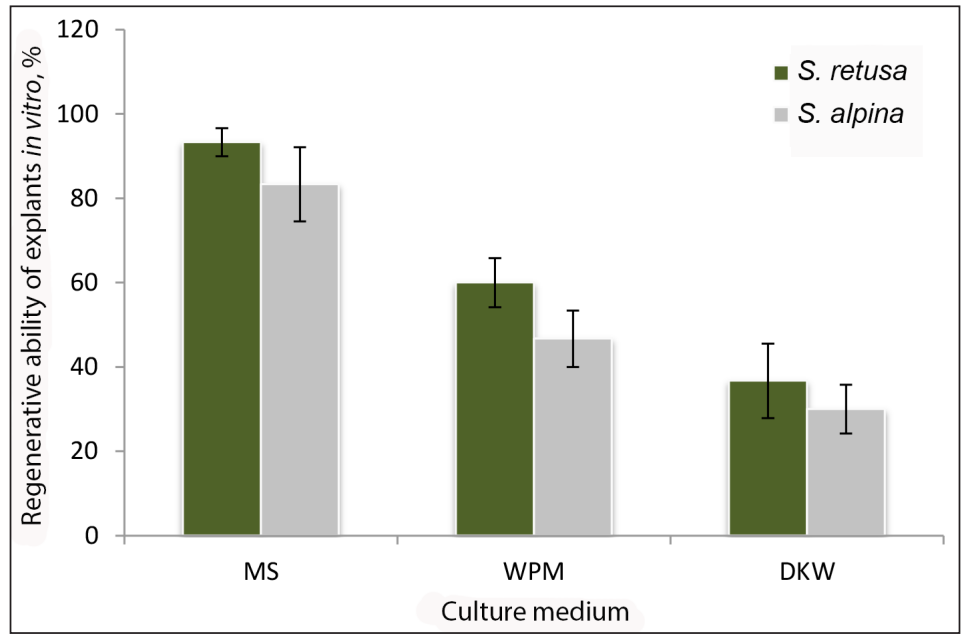

Fig. 2. Effect of different nutrient media on the regenerative ability of explants of $S$. retusa and S. alpina at the stage of their introduction into in vitro culture (days $25-30$ of cultivation)

Table 2. Characteristics of $S$. retusa and $S$. alpina plant-regeneration growth by cultivation on modified MS nutrient media (35-40 days in culture in vitro)

\begin{tabular}{|c|c|c|c|c|c|c|}
\hline $\begin{array}{l}\text { Vari- } \\
\text { ant of } \\
\text { experi- } \\
\text { ment }\end{array}$ & Nutrient medium & $\begin{array}{c}\text { Average } \\
\text { value of } \\
\text { microshoots, } \\
\text { cm }\end{array}$ & $\begin{array}{l}\text { Average number } \\
\text { of microshoots } \\
\text { on one explant, } \\
\text { pcs }\end{array}$ & $\begin{array}{l}\text { Colour of } \\
\text { explants }\end{array}$ & $\begin{array}{c}\text { Type of } \\
\text { morphogenesis }\end{array}$ & $\begin{array}{l}\text { Root forma- } \\
\text { tion, pcs }\end{array}$ \\
\hline control & basal MS & $1.6 \pm 0.1$ & $1.5 \pm 0.3$ & green & $\begin{array}{l}\text { Activating the growth } \\
\text { of available meristems } \\
\text { of explants }\end{array}$ & - \\
\hline 1 & $\mathrm{MS}+0.25 \mathrm{mg} / \mathrm{l} \mathrm{kin}$ & $2.0 \pm 0.2$ & $1.5 \pm 0.3$ & $-1 /-$ & $\begin{array}{l}\text { Activating the growth } \\
\text { of available meristems } \\
\text { of explants }\end{array}$ & - \\
\hline 2 & $\begin{array}{c}\mathrm{MS}+0.25 \mathrm{mg} / \mathrm{l} \mathrm{kin} \\
+2 \mathrm{~g} / \mathrm{l} \text { activated } \\
\text { carbon }\end{array}$ & $3.0 \pm 0.2$ & $3.2 \pm 0.2$ & $-1 /-$ & $\begin{array}{l}\text { Activating the growth } \\
\text { of available meristems } \\
\text { of explants }\end{array}$ & - \\
\hline 3 & $\begin{array}{l}\mathrm{MS}+0.5 \mathrm{mg} / \mathrm{lkin} \\
+2 \mathrm{~g} \mathrm{~L}^{-1} \text { activated } \\
\text { carbon }\end{array}$ & $3.6 \pm 0.2$ & $3.0 \pm 0.4$ & $-1 /-$ & $\begin{array}{l}\text { Activating the growth } \\
\text { of available meristems } \\
\text { of explants }\end{array}$ & - \\
\hline 4 & $\mathrm{MS}+0.5 \mathrm{mg} / \mathrm{l} \mathrm{BA}$ & $1.7 \pm 0.1$ & $1.5 \pm 0.5$ & $\begin{array}{l}\text { light- } \\
\text { green }\end{array}$ & $\begin{array}{l}\text { Activating the growth } \\
\text { of available meristems } \\
\text { of explants }\end{array}$ & - \\
\hline 5 & $\mathrm{MS}+1.0 \mathrm{mg} / \mathrm{lBA}$ & $1.2 \pm 0.1$ & $1.5 \pm 0.3$ & $-1 /-$ & $\begin{array}{l}\text { Activating the growth } \\
\text { of available meristems } \\
\text { of explants }\end{array}$ & - \\
\hline 6 & $\mathrm{MS}+1.0 \mathrm{mg} / \mathrm{l} 2-\mathrm{iP}$ & $1.1 \pm 0.1$ & $1.2 \pm 0.2$ & $-/ /-$ & $\begin{array}{l}\text { Activating the growth } \\
\text { of available meristems } \\
\text { of explants }\end{array}$ & - \\
\hline
\end{tabular}

pigmentation was obtained on days 35-40 of cultivation, but formation of roots on explants was not noted (Fig. 1 e, f).
Addition of a range of antioxidants - glutathione $2.0 \mathrm{~g} / \mathrm{l}$, adenine $1.0 \mathrm{~g} / \mathrm{l}$, glycine $1.0 \mathrm{~g} / \mathrm{l}$ and $2 \mathrm{~g} / \mathrm{l}$ of activated carbon - to MS nutrient 
medium significantly improved the processes of microparticle growth, probably because of the decrease in the secondary metabolite activity. In the case of adding $0.5 \mathrm{mg} / \mathrm{l} \mathrm{BA}$, or $1.0 \mathrm{mg} / \mathrm{l} \mathrm{BA}$, or $1.0 \mathrm{mg} / \mathrm{l} \mathrm{2-iP}$ to MS nutrient medium, the length and the number of regenerated segments on explants were significantly lower than those of variants 2 and 3. Consequently, as a result of our research, we obtained aseptic and morphogenic active explants of S. retusa and S. alpina ready for the next stage of mass multiplication in vitro.

Our further research is aimed at developing biotechnology for microclonal propagation of S. retusa and S. alpina for their successful rooting in vitro and their adaptation to ex vitro conditions.

We have developed part of biotechnological procedures that can be useful in conserving rare and endangered species of willows.

\section{CONCLUSIONS}

1. Our direct plant regeneration system attempts using shoot and nodal segments were successful and could be applied in the conservation of endangered willow species.

2. Effective sterilization (over $80 \%$ ) of S. retusa and S. alpina explants was achieved by applying the stepwise method, which consisted of consistently maintaining the explants in a number of solutions for 5-6 min in each: $0.1 \%$ $\mathrm{HgCl}_{2}, 1.0 \% \mathrm{AgNO}_{3}$, and $2.5 \% \mathrm{NaClO}$. In spite of high contamination of natural explants, such kind of sterilization was successfully applied.

3. At the stage of their introduction into in vitro culture, S. retusa and S. alpina isolated explants were cultivated on selected media. Among various tested and optimized media for the sterile morphogen culture, the basal MS medium with a range of antioxidants (glutathione $2.0 \mathrm{~g} / \mathrm{l}$, adenine $1.0 \mathrm{~g} / \mathrm{l}$, and glycine $1.0 \mathrm{~g} / \mathrm{l}$ ) was the most efficient one. In this case, a significant regeneration capacity was observed in S. retusa and $S$. alpina explants (explant regeneration frequency of over $80 \%$ ).

4. Micropropagation attempts using shoot and nodal segments from stem-origin explants of S. retusa and S. alpina in vitro were successfully recovered on MS medium with 0.25$0.5 \mathrm{mg} / \mathrm{l}$ kinetin and $2 \mathrm{~g} / \mathrm{l}$ activated carbon.

\section{ACKNOWLEDGEMENTS}

The scientists who conducted this research were supported by an internal grant of the $\mathrm{Na}$ tional University of Life and Environmental Sciences of Ukraine (No. 0117U004402). All necessary permits were obtained for manipulating with endangered species ( $S$. retusa and S. alpina) and collecting plant material in protected areas.

Received 2018 September 6 Accepted 2019 April 5

\section{References}

1. Bilous S, Chornobrov O, Overchenko O. Preservation of ancient and old value trees of Ukraine with using biotechnology methods. Litteris et Artribus [Internet]. 2017 Nov [cited 2018 May 28] [about 4 P.] Available from: http://ena.lp.edu.ua:8080/handle/ ntb/40518

2. Butenko RG. Cell biology of higher plants in vitro and biotechnology on their base. Training manual. 1999. Russian.

3. Bonga JM and Durzan DJ, editors. Cell and tissue culture in forestry, vol. 1: General principles and biotechnology. Dordrecht: Martinus Nijhoff Publishers; 1987.

4. Driver JA, Rodriguez R, Kuniyuki AH. In vitro propagation of Paradox walnut Juglans hindsi $\times$ Juglans regia rootstock. HortScience; 1984 . 19: 507-9.

5. Ishchuk LP. Analysis of Willow (Salix L.) flora in Ukraine Carpathians. J Bot. 2017; 1(14): 50-5.

6. Kalinin FL, Sarnatskaya VV, Polishchuk VE. Methods of tissue culture in plant physiology and biochemistry. Kiev: Naukova dumka; 1980. 488 p. Russian. 
7. Kandel SL, Firrincieli A, Joubert PM, Okubara PA, Leston ND, McGeorge KM, Mugnozza GS, Harfouche A, Kim S, Doty SL. An in vitro study of bio-control and plant growth promotion potential of Salicaceae endophytes. Front Microbiol. 2017; 13; 8: 386.

8. McCown BH, Lloyd G. Woody plant medium (WPM) - a mineral nutrient ormulation for microculture of woody plant species. HortScience, 1981; 16: 453.

9. Mohan J, Ishii K. Micropropagation of woody trees and fruits. Kluwer Academic Publisher, 2003; 940.

10. Murashige T, Skoog F. A revised medium for rapid growth and bioassay with tobacco tissue cultures. Physiol Plant. 1962; 15(3): 473-97.

11. Malynovskyi K, Tsaryk Y, Kyiak V, Nesteruk Yu. Rare, endemic, relict and boundaryarbal species of plants of the Ukrainian Carpathians. Liha-Pres, 2002; 76. Ukrainian.

12. Shi D. Effects of culture media and plant growth regulators on micropropagation of willow ( $\mathrm{Sa}$ lix matsudana 'Golden Spiral') and hazelnut (Corylus colurna 'Te Terra Red'). [dissertation]. University of Nebraska - Lincoln; 2014.

13. Park SY, Kiim YW, Moon HK, Murthy HN, Choi YH, Cho HM. Micropropagation of Salix pseudolasiogyne from nodal explant. Plant Cell Tissue Organ Culture, 2008; 93: 341-6.

14. Read EP, Bavougian CM. In vitro rejuvenation of woody species. Protocols for micropropagation of selected economically - important horticultural plants. Methods in molecular biology, 2013; 994: 383-95.
15. Smith RH. Plant tissue culture: techniques and experiments. 3rd edition. Amsterdam: Academic Press; 2012; 33-101.

16. Red Book of Ukraine. 2010-2018; [cited 2017 May 2]. Available from: http://redbook-ua. org/category/Salicaceae. Ukrainian.

17. Convention for the protection of biological diversity. 1994; [cited 2017 May 2]. Available from: https://zakon.rada.gov.ua/laws/ show/995_030. Ukrainian.

18. Pan-European strategy for the conservation of biological and landscape diversity. Sofia; 1995. Ukrainian.

19. Resolution of the Cabinet of Ministers of Ukraine. About the concept of biological conservation diversity of Ukraine. Kiev, 1997; N439. [cited 2017 May 2]. Available from: https://zakon.rada.gov.ua/laws/show/439-97. Ukrainian.

20. Law of Ukraine on Environmental Protection. 1991; No. 41, 546-547; No. 1268-XII. [cited 2017 May 2]. Available from: https://zakon. rada.gov.ua/laws/show/1264-12. Ukrainian.

21. Law of Ukraine on nature reserve fund of Ukraine. 1992: No. 34, 502-503. [cited 2017 May 2]. Available from: https://zakon.rada. gov.ua/laws/show/2456-12. Ukrainian.

22. Law of Ukraine on flora. 1999; No. 22-23, 198; No. 591-XIV. [cited 2017 May 2]. Available from: https://zakon.rada.gov.ua/laws/ show/591-14. Ukrainian.

23. Identifier of plants of the Ukrainian Carpathians. Kiev: 1977. 434 p. Ukrainian. 
Oksana Chornobrov, Svitlana Bilous,

Oleksandr Chornobrov, Maria Manko

NYKSTANČIOS GLUOSNIO (SALIX SPP.) RŪ-

ŠIES MORFOGENEZĖS YPATUMAI IN VITRO

\section{Santrauka}

Retų Salix L. rūšiu genotipų, ypač uolinio karklo

(Salix retusa L.) ir karklo Salix alpina Scop., esančių Ukrainos Raudonojoje knygoje, išsaugojimas ir dauginimas yra viena svarbiausių dabartinių užduočių. Šio tyrimo tikslas buvo sukurti in vitro S. retusa ir S. alpina kultūras, kad būtų galima jas išsaugoti ir dauginti. Augalinè medžiaga buvo kultivuojama pagal MS, WPM, DKW parinktoje auginimo terpèje, papildomai pridèjus augimą reguliuojančių preparatų. Efektyvus S. retusa ir S. alpina tirpalų sterilizavimas (daugiau kaip $80 \%$ ) buvo pasiektas laipsniškai palaikant tirpaluose 5-6 min.: $0,1 \% \mathrm{HgCl}_{2}$, $1,0 \% \mathrm{AgNO}_{3}$. Ženklinant tirpalų regeneraciją pagal in vitro meristemas, nustatyti reikšmingi rezultatai pridèjus 0,25-0,5 mg/l 6-furfurilaminopurino, kinetino ir $2 \mathrm{~g} / \mathrm{l}$ aktyvintos anglies. Mūsų tolesni tyrimai bus skirti S. retusa ir S. alpina mikrokloniniam dauginimui, jų išsaugojimui ir reprodukcijai in vitro.

Raktažodžiai: išsaugojimas, Salix L., eksplantas, mikrokloninis dauginimas 